\title{
СПЕЦИФИКА ПРОЯВЛЕНИЯ НРАВСТВЕННЫХ ОТНОШЕНИЙ КУРСАНТОВ В СЛУЖЕБНОЙ ДЕЯТЕЛЬНОСТИ
}

\section{SPECIFICITY OF MANIFESTATIONS OF MORAL RELATIONS OF CURSANTS IN OFFICIAL ACTIVITIES}

\section{Kharchenko}

Summary: The article discusses the moral features of the border cadets. Attention is paid to the specifics of the border service. The concept of moral relations of cadets is interpreted. The bases of moral relations, such as spirituality, operational thinking, military mentality, are examined. The formation of moral relations is considered from the point of view of the activity approach. The conclusion is drawn about the importance of moral self-control.

Keywords: moral relations, morality, spirituality, military mentality, border service.

\author{
Харченко Денис Владимирович, \\ Адьюнкт, Военный университет \\ Министерства Обороны Российской Федерации \\ d_xarchenko@mail.ru
}

Аннотация: В статье рассматриваются особенности нравственной сферы курсантов-пограничников. Уделяется внимание специфике пограничной службы. Интерпретируется понятие нравственных отношений курсантов. Рассматриваются такие основания нравственных отношений, как духовность, операциональное мышление, военная ментальность. Формирование нравственных отношений рассматривается с точки зрения деятельностного подхода. Делается вывод о важности нравственного самоконтроля.

Ключевые слова: нравственные отношения, мораль, духовность, военная ментальность, пограничная служба.
A ктуальность проблемы формирования нравственных отношений курсантов, проявляемых в служебной деятельности, обусловлена тем, что повседневная жизнь и служба офицера-пограничника основана на огромном количестве самоограничений. Она проходит в самых отдаленных рубежах нашей страны, где бывает так, что до ближайшего населенного пункта, где есть хоть какая - то социальная инфраструктура - сотни километров.

Бесспорно, что для подготовки офицера к службе в вышеописанных условиях у него должна быть сформирована особая нравственная позиция, основанная на глубоком патриотизме и идейной убежденности в необходимости выполнения воинского долга по защите Родины, с готовностью к «жертвенному служению», исключающему большинство цивилизационных благ из повседневной жизнедеятельности человека.

При этом, развитие нравственных качеств возможно при интеграции профессиональной этики офицера пограничной службы в систему общечеловеческих моральных норм и ценностей, основанных прежде всего на принципе гуманизма [4].

Для этого уже на этапе воспитательного процесса в образовательных организациях пограничного профиля требуется особая система психолого-педагогического сопровождения становления нравственного отношения курсанта к миру, к другим людям и к себе. В рамках системно-деятельностного подхода формирование нравственных отношений курсантов и их проявления в исполнении служебных обязанностей рассматривается нами как непрерывный процесс личностных преобразований учащихся военных вузов. Нравственные отношения личности курсантов - это активные, сознательные, интегральные, избирательные связи, основанные на интериоризованном из военно-профессиональной среды опыте социального взаимодействия по реализации нравственных ценностей.

Нравственные отношения курсантов, реализуясь во всех сферах их жизнедеятельности отражаются в их нравственных суждениях; нравственном поведении и нравственных чувствах, что, соответственно, позволяет говорить о когнитивном, поведенческом и эмоционально-чувственном компонентах структуры нравственных отношений.

Кроме того специфика военной службы выдвигает требования к особенному аспекту воинской нравственности: к мотивационным и волевым ее проявлениям. Нравственные отношения курсантов отражают весь набор когнитивных образований, сложившихся у личности в процессе общей и профессиональной социализации в ходе военной службы. Это все те понятия, правила и законы, которые курсант усвоил в процессе воинского обучения и воспитания, результатом которого стало его психологическое новообразование «Я- военнослужащий».

Это переведенные во внутренний план и «принятые 
как свои» требования воинской службы и осмысленная готовность подчиняться правилам и требованиям Уставов и нормативных документов, предписывающих те или иные нормы поведения.

Моральные новообразования курсантов, возникающие в период обучения, включают, прежде всего, моральные ценности: добро, справедливость, честность, благо, достоинство и т.д.

Еще одним новообразованием в нравственной сфере курантов можно считать появление особой военной «ментальности». Ментальность - это понятие включающее в себя взгляды, оценки, ценности, нормы поведения и морали, умонастроения, религиозную принадлежность и многие другие нюансы, характеризующие ту или иную группу людей.

Содержанием ментальности курсанта, определяющей его нравственное отношение к специфической окружающей его действительности, к другим людям в ней, и к себе самому становятся все те знания, понятия и осмысленные установки, которые становятся личными жизненными ценностями, составляющими ту призму нравственных образцов, через которую будет проходить процедура оценивания и принятия решения о совершении того или иного действия или поступка.

Итак, основой нравственных отношений курсантов военных являются нравственные знания, то есть знания нравственных принципов и норм воинского поведения и профессиональная идентичность «Я - русский офицерпограничник».

Нравственное развитие курсантов тесно связано с духовной сферой сознания и личности. Невозможно формирование устойчивых нравственных отношений, если человек движим только базовыми потребностями. Моральное сознание личности входит в духовный внутренний мир, наряду с эстетическим мировосприятием, смысложизненными основаниями самосознания. Обусловленная общечеловеческими истинами добра, любви и красоты и т.п., духовность непосредственно связана с нравственностью, ибо нравственный компонент в человеке - это комплекс характеристик мотивационной и информативной сферы жизнедеятельности, основу которого определяет система ценностей, установок и мотивов поведения индивида в обществе.

Можно согласиться с мнением Д.А. Леонтьева, который предлагает рассматривать духовность как высший уровень человеческой саморегуляции, присущий зрелой личности (считая, что в этом аспекте духовность тесно связана с самодетерминацией) [1, с. 18].

Н. В. Марьясова рассматривает духовность как прин- цип саморазвития и самореализации человека, обращения к высшим ценностным инстанциям конструирования личности, считая, что и развитие, и самореализация духовного Я субъекта начинается тогда, когда он осознает необходимость определения для себя того, как он конкретно должен понимать общечеловеческие духовные ценности - истину, добро, красоту [2, с. 79].

Формирование личностной зрелости, духовности и нравственных отношений современными исследователями рассматривается как один из аспектов когнитивного развития личности. Так, А.Т. Москаленко и В.Ф. Сержантов подчеркивают, что «когнитивное развитие состоит не только в углублении познания, но и в таком качественном видоизменении интеллекта, которое связано с изменением позиции познающего субъекта по отношению к миру. Переход к операциональному мышлению обеспечивает преодоление эгоцентризма, и, следовательно, становление личностного самосознания, оформление «Я-концепции» [3, с. 36].

Ж. Пиаже указывает на социальные факторы, влияющие на развитие

познавательных способностей индивида - наряду с психическим созреванием, - это социальная среда и индивидуальный опыт [5]. Переход к периоду формирования операционального мышления связан, с одной стороны, с ходом созревания, а с другой - с последовательностью воздействий социальной среды, в форме обучения и воспитания.

Начав сознательно подбирать способы общения в служебном

подразделении, курсант осваивает путь совершенствования значимых для себя качеств личности. В период профессиональной подготовки в вузах ФСБ России пограничного профиля характер учебно-служебной деятельности содействует тому, что возникают новые мотивы учения, связанные с осознанием жизненной перспективы, собственного места в жизненном и профессиональном пространстве. На этой почве формируется более высокий уровень познавательных интересов. Интересы становятся более устойчивыми, перестают носить эпизодический характер. Под воздействием потребности в новом, курсантами прилагаются специальные усилия для расширения знаний в различных областях действительности, в том числе профессиональном, личностном, нравственном развитии.

Однако, процесс реализации потребности курсанта в познании как любой процесс развития, обладает внутренним противоречием. Оно выражается в присущем молодому человеку слабом багаже знаний, являющемся основой осуществления познавательного процес- 
са. Слабые знания, среди которых могут иметь место и знания негативного порядка, благодаря случаю, могут направить познавательные интересы курсанта в направлении, совершения аморального или противоправного поведения. Познавательные интересы, способствующие усвоению негативной информации, приводят к разрушению личности, приобщению ее к таким видам деятельности, которые наносят вред как обществу, так и самой личности.

Особенности проявления нравственных отношений курсантов в служебной деятельности обусловлены спецификой военно-профессиональной деятельности и во- енно-образовательного процесса в вузе. Нравственные отношения проявляются в основанном на развитой духовности как осознанности своих действий, операциональном мышлении, усвоенных моральных ценностях и нормах поведении при исполнении военно-служебных обязанностей и в повседневной жизни. Это невозможно без самоконтроля и саморегуляции, без того, чтобы взвешивать свои действия с учетом сформированных на уровне самосознания моральных императивов и военной ментальности. Подобные самоконтроль и саморегуляция необходимы в условиях тех лишений и ограничений, с которым сопряжена военно-профессиональная деятельность офицера-пограничника.

\section{ЛИТЕРАТУРА}

1. Леонтьев Д.А. Духовность, саморегуляция и ценности // Гуманитарные проблемы современной психологии. Изв. Таганрогского гос. радиотехн. ун-та. 2005. - № 7. - С. 16-21.

2. Марьясова Н.В. Духовность личности как социокультурный феномен // Психология человека в современном мире. - Т 6. Духовно-нравственное становление человека в современном российском обществе. Мат-лы Всерос. юбил. науч. конф., посвящ . 120-летию со дня рождения С.Л. Рубинштейна / отв. ред. А.Л. Журавлев и др. М.: Ин-т психологии РАН, 2009. - С. 77-85.

3. Москаленко А.Т. Личность как предмет философского познания. / А.Т. Москаленко, В.Ф. Сержантов. - Новосибирск: Наука. - 1984. - 264 с.

4. Мяготин А.В. Профессиональная этика сотрудника пограничных органов как социальная система (социально-философский анализ): Дисс... докт. . . филос. наук. - М., 2011. -392 с.

5. Пиаже Ж. Психология интеллекта. - М.: Директ-Медиа, 2008. - 351 с.

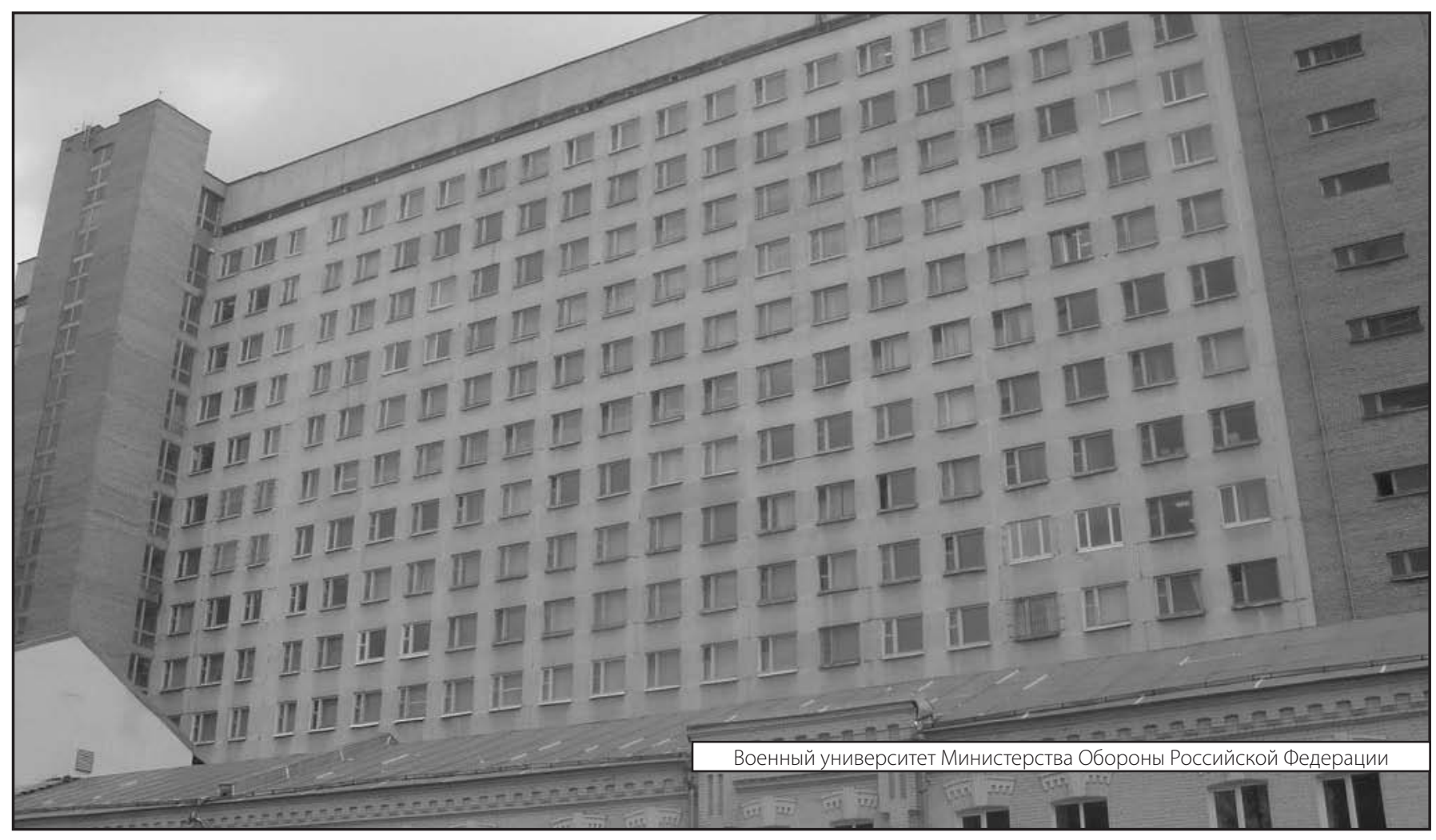

